Cite as: Mitchell, S., \& Eiroa-Orosa, F. J. (2018). Love your enemy? An aesthetic discourse analysis of selftranscendence in values-motivated altruism. Global Discourse. https://doi.org/10.1080/23269995.2018.1511766

\title{
Love your enemy? An aesthetic discourse analysis of self-transcendence in values-motivated altruism
}

\author{
Sue Mitchell
}

Francisco Jose Eiroa-Orosa

Section of Personality, Assessment and Psychological Treatment, Department of Clinical Psychology and Psychobiology, University of Barcelona; Program for Recovery and Community Health, Department of Psychiatry, Yale University School of Medicine

\section{ABSTRACT}

Inter-disciplinary academic enquiry shares the challenge to explore the social and ethical applications of research into today's globalised but increasingly complex world. Positive psychology examines how life can be well in this broader enquiry of the social and moral contexts of 'individual' happiness. In this it begins to embrace innovative, qualitative research methods alongside its earlier positivistic, scientific approach, in the social transition to enquire more inductively. This research therefore attempts two things. The substantive research explores how experiences of self- transcendence may emerge in the choice of altruistic values, to 'love an enemy', potentially at cost to personal 'selfhood' in pur- suit of a well society. Secondly, it presents the innovative 'aes- thetic discourse analysis' as a means to examine the motivational or moral impulse of personhood, where the self becomes 'sensible' to agentic change. It draws on Bakhtin's use of genre, emotional intonation and chronotope to interrogate the 'feltness' of selfconscious motivation. In three focus groups, people who are all committed to the selftranscendent value to love the Other, con-verse with Others from different backgrounds and belief systems. The research discovers that lived experiences of self-transcen- dence co-occur with ontological and epistemological re-shaping of self-consciousness.

\section{KEYWORDS}

Word; transcendence; consciousness; self; agency; dialogic 


\section{Introduction}

Study into the nature of 'the self' as a conscious being has mushroomed in recent years (Baumeister 1987, 2011) with the Cartesian 'bounded, separate' individual (Westerman 2013) and the eradication of any 'distinction between world and mind, object and subject' (Gergen 1991, 103) at the outer perimeters of the discussion. A post-modern reaction to modern positivism, the latter position, as a social constructionist view, might now give way to the emerging social shift towards an integrative approach (e.g. Lomas, Hefferon and Ivtzan 2014). Such integration of cross-cultural perspectives and practices into selfhood (Kwee 2011; Wong 2012), strengthens the appeal for a moral, ethical or spiritual dimension to the study, where 'transcendence' has become a frequent, but very varied reference, (e.g. Schnell 2011; Schwartz 1994). The intention is therefore to explore what self-transcendent experience exposes of our understanding of selfhood, and of its being potentially re-shaped, reflectively and ethically.

\section{The hypothesis}

This is that self-transcendence (ST) would be evident in 'going beyond' an evolutionary self-preserving consciousness, and an interrogation of the potentially transcendent selfconscious behaviour associated with love for an 'enemy' other, will also address the research gap into value-motivated altruism (Batson, Ahmad, and Lishner 2009) and into compassionate love (Oman 2011). Darley and Batson (1973) examined the religious motivation for helping values which resulted 'far less often than expected' in helping behaviour. This enquiry, using the same narrative text as Darley and Batson (1973), explores loving behaviour towards an enemy as a human value-motivated altruism, which in principle transcends the self-interested, kinship selection, self-expansion or other egoistic motivations of altruism (Dugatkin 2006). It is further hypothesised that, at the point where 'self-sacrificing' behaviour is specifically valued, an agentic self may emerge in pursuit of self-authored altruistic values from among a polyphony of competing voices.

\section{Self-transcendence as an agentic self}

Reference to ST is multi-faceted in the literature. Both Maslow (1971) and Frankl (1966) suggested that ST is a values-oriented aspect of humanness, which, though strongly disapproved then, today may help 'bridge between the cross-cultural values literature and a major theory of motivation' (Koltko-Rivera 2006, 313). Values-creation is a 'primary, or native orientation' (Frankl 1966, 98) of a transcendent human, or 'deciding' being (Frankl 2011). Piedmont's (1999) enquiry into 'spiritual' transcendence sees it as 'a fundamental capacity of the individual, a source of intrinsic motivation, that drives, directs and selects behaviours' (988). His measurement scale however references 'individual' personality rather than values, with a somewhat positivistic bias, viewing 'life from a larger, more objective perspective' (Piedmont 1999, 988). Cloninger's (1999) and 
Reed's (2009) ST scales draw heavily on a medical model, inappropriate to a more explorative, philosophical enquiry; Haase et al's (1992) concept paper is more helpful; it identifies three facets of ST 'as reaching out beyond self-concern, stepping back from and moving beyond what is, and extending self-boundaries inwardly, outwardly and temporally' (Haase et al. 1992, 144).

A reflective, potentially agentic self is implicit in such self-transcendent movement from or beyond, inward, outward or time-imposed limitation, and suggests an enquiry into moments of awareness of such movement, and the boundaries which this sensitiv- ity encounters. As such it resonates with the 'in-between' of Gadamer's (2004) philosophical hermeneutical approach to understanding, and the 'moment of transcendence in which we come to understand ourselves differently' (Davey 2006, xi). Selfunderstanding in such a moment should not be understood as the 'deciding being' finally emerging but Gadamer's approach does imply the self's responsiveness to the moment where, in dialogue with an Other, a culturally and socially located individual becomes 'sensible' of the interaction between many voices and 'entails an ethical disposition' (Davey 2006 loc 1584). Gadamer's 'sensibility' is first felt as an emotional disturbance in becoming aware of the centripetal pull of socio-cultural and familiar, other-authored, voices which tell us who and how we 'should' be (Gadamer 1981). This research thus seeks to explore this sensibility as the experience of Haase's transcendence, firstly as awareness of such 'social embeddedness' and then potential movement away from it and towards 'a felt sense of responsibility' (Sullivan and McCarthy 2004, 296), and more agentic participation in shared, lived experience.

\section{Discursive psychology}

To research potential evidence of a movement towards self-transcendence in such a moment of self-aware understanding will therefore require 'a lived context' and suitable analytical tools to measure and compare different psychological and social interactions. In the ongoing discussions around the strengths and weaknesses of a qualitative approach to analysis, Discursive Psychology (DP) and Conversational Analysis (CA) have been in the forefront of criticism and responses. Stokoe, Hepburn and Antaki, (2012) suggest we 'see Frosh, 1999; Parker, 2005: 91-92; for replies, see Edwards, Ashmore \& Potter, 1995; Edwards, 2006; 2007'. The distinctive strength that DP offers is a 'change of analytic focus ... (which) investigates how "psychology" and "reality" are produced, dealt with and made relevant by participants in and through interaction.' (Hepburn and Wiggins 2005, my itals). Hepburn and Wiggins (2005) argue for the necessity of a DP approach as one able to discern the deep biases built into certain methodological approaches, which philosophical hermeneutics also terms a 'woeful insensitivity' (Davey 2006 loc 1498), and which potentially contribute to a lack of transformative change. The fresh focus that DP offers is to look for the nuances and movement that can take place between people in social interaction, where Tileagă (2006) particularly argues moral discourse is constructed, and can be discerned in 'the intricacies of discourse'. Given the hypothesis of the potential discovery of moments of self-transcendence in an analysis 
of conversation in real time and lived experience, how might such intricate moments be identified in the discourse?

\section{Aesthetic discourse: genre, time-space elaboration and emotional intonation}

Aesthetic discourse analysis (ADA) (Sullivan 2012), is helpfully innovative in its focus on interrogating Gadamer's feltness of the self's probing movement towards potential reshaping. As such, it offers a similar novelty to that which DP suggests, that individuals, in situated practices and in interaction with difference, may find and express a resource to struggle against the deep 'matrix of abstract social processes' (Hepburn and Wiggins 2005). Such novelty is probably essential to interrogate these depths, especially in the times of such social and political upheaval which this journal edition addresses, 'with contributors (who) are innovatory and applied researchers' (personal communication). I gladly admit to the axiology of employing deep-structural and hopeful methods as means towards hopeful and deeply renewing ends, should the hypothesis prove correct. I am equally persuaded by ADA as an empirically stringent discourse analytical tool which draws on Bakhtin's work on the polyphonic novel (Bakhtin 1981). He describes the analysis of genre, emotional affect, and imaginatively embodied time-space motifs as the affective, intoned 'language' of this potential sensibility. This combination makes it specifically appropriate to investigating the 'alogical' facet of personhood associated with both the moral conscience (values) and love itself (Frankl 2011) in this research.

Genre has long been studied and functioned as a literary device. In the conversa- tional interactions of this research however, genre is not understood as 'instituted' (Maingueneau 2002), where it pre-determines the kind of discourse required in any given situation, such as an academic paper. Nor are genres 'fixed schemata' (Keunen 2000) of pre-emptive social patterning in the discourse. Though genre can and does function in both these ways, and dialogic conversation certainly engages with the implicit connotations generated by invoked genres, certain types of genre may generate potential at the 'in-between' of what was and what may be, towards the possibility of re- shaping individual and collective consciousness.

Stern (2010) speaks of different types of life experience as 'Forms of Vitality', as 'Gestalt', or whole, experiences which involve, at a phenomenological level, direction, (i.e. approach or withdrawal), intentionality and embodiment in time and space coming together. Discourse, like movement, is a form of vitality with these phenomena hidden within it. Particular genres, or types of discourse, carry in them these 'whole' experiences as deeply coded shapes in our discourse which we feel in and through the conversation, and which carry different demands on us. Based in Bakhtin's well researched theories, this enquiry will interrogate the phenomenon of the directionality of the discourse, which he refers to as 'outside-in', 'inside-out' or, specifically, 'doublevoiced', to track if there are resonances with changes of sensibility.

Chronotope is the finer-grained analysis of genre which exposes how its component elements of movement, time, space and intention are differently configured. If we 
examine the chronotope's own meaning in two different genres, we can perceive the different configurations in which it too can be experienced, and, importantly, felt. For instance, a chronotope, in scientific text, is a 'four-dimensional mental image(s) combining the three spatial dimensions with the time structure of temporal action' (Keunen in Borghart et al. 2010). As such, at its own 'chronotopic' level, it is imagined as a defined space, high, wide and long; a cube then, with time, measured in relation to space as movement, somehow implicated. So this strong box-like structure moves and we observe, passively. For us there is no access, our understanding is static, and the potential of the situation and our responsibility in it is limited. We may then feel frustrated by the 'objective' description, and actually experience the chronotope as a 'Gordion knot without an Alexander in sight' (Holquist 2010, 19)! We feel the mental paralysis of a knotted understanding, and intone it with an exclamation mark. Yet within this second chronotope, a different future is also implicit. An Alexander will arrive with a newly imagined solution, in which role we are invited to participate. We sense this future potential and the challenge to move towards it. So different genres (scientific or tragic) of lived experience will be configured in chronotopic detail; that is the timeorientation and spacial definition evoked in the discourse, whether small or large, open or closed, which can be observed, approached or avoided, fast or slowly. The specific configuration will animate different emotional affect.

Emotional intonation, the speeded-up discourse, the ironic giggle, the raised voice, become descriptors of the feeling self's sensibility to different scenarios. Chronotope, traced in the time, space and movement evoked in the discourse, and emotional register, heard in the intonation, are our second and third means of tracing the changes in sensibility of the Self's 'intuitively' reflective, potentially transcendent movement (Frankl 2011). With these tools to hand we approach the research.

\section{Method}

Conversations in focus groups would be recorded for subsequent discourse analysis. Ethical approval was received from the University of East London Ethics Committee.

\section{A. data collection of dialogic discourse}

\section{(1) Participants}

The first researcher works across the UK and Europe in organisational change in statutory provision of education and health, and charities, in particular faith communities. This usually involves consideration of negotiating strongly held values and beliefs in an increasingly pluralistic, secularised society. At the same time, the organisational structures of western political systems, including at the local level, have come under severe pressure from globalised 'biopower', whereby it is suggested that the 'sovereignty' of global capital, law and war has subsumed transcendence itself (Mitchell 2011). In response, both new political awareness (Agamben 1998), new theological thinking 
(Ward 2005) and new community initiatives (Love 2013) are exploring a freshly 'transcendent', love-based motivation as an alternative radical enough to contest this hegemony. The researcher drew on these inter-disciplinary, long-term relationships to investigate this transcendence at a psychological level. Three co-ordinators introduced the researcher to potential participants. Each received a personal email to explain the process and, if happy to engage with it, was asked to sign the consent form, which included an affirmation of a 'desire to love rather than harm a potential enemy, and the commitment to love such an "other" person as important to me'. Participants were invited to dialogue with others holding the same values but who also embodied difference, with a view to capturing discourse about altruistic behaviour which might itself evoke the transcendent movement of reflective self-reshaping in dialogue with a different 'other'. As dialogism may be with a text as well as with other persons, the conversation was initiated around the ancient text of 'The Good Samaritan' which discusses values-led motivation and behaviour. Arguably, within its own context, the text also provoked a re-framing of social norms (Alison 2007).

\section{Procedure}

Focus groups. Despite a normative expectation of consensus (Halkier 2010) counterintuitive to this enquiry, conversation in focus groups offered broader experience of difference than dialogue or interview; collection of sufficient data within a limited time frame; and potential comparison between the different groups' data.

- The first focus group (FG1), a quasi-control group,1 embodied only individual differences between 11 Christian-background men and women from a rural English community, aged 34 to 67 . All have withdrawn from participation in religious structures but hold to values and beliefs they live out politically at an individual level.

- $\quad$ The second group (FG2) was constituted in a city where peace activists have built relationships between different faith and cultural groups. It consisted of 7 women and men, aged 18 to 66, from the Muslim, Sikh, Christian, Jewish and non-faith communities. These, though holding widely dissimilar beliefs, draw on commonly shared altruistic values, to impact the wider socio-political landscape.

- A third group (FG3) of 11 was convened with volunteers from 10 different ethnic backgrounds, from Venezuela to Uzbekistan, Uganda to Germany, working tem- porarily in a Christian community. $85 \%$ were under 30; all are involved in a values- defined community.

A dialogical approach indicates an interested axiology and the researcher's participation is included and was explained to each group at the outset. 
Qualitative conversational analysis. Within a predominantly scientific psychology this requires clarifications of expectations and epistemological framework (Madill, Jordan, and Shirley 2000). This exploratory research did not aim to fulfil the expectations of a realist scientific framework but did seek to follow such authenticating protocols of the scientific community to establish its research credibility. It therefore adopted a strict and systematic procedure to process all the data.

- The conversations were fully transcribed as described by Ten Have (2015), covering the main symbols used in conversational analysis, but including some newly invented codes, e.g. *the sound of smiling*, since intonation is such an important factor in this analysis.

- $\quad$ The discourse was closely examined for Key Moments (KM) where at least two of the three factors, genre, chronotope or intonation, changed significantly and at the same time.

- Recognising the analyst's interpretation in the selection of these key moments will, to an extent, be a 'charismatic' application of 'bureaucratic' processes (Sullivan 2012), the conversations were concluded with a time for participants to reflect and record their experience of any moments that felt significant to them as an important balancing factor.

- $\quad \mathrm{KMs}$ were then entered into Key Moments Overview Charts (KMOC) to track the overall movements of the different conversations.

The key question put to the data was 'Where and how is the self being potentially reshaped in multi-voiced interaction?'

\section{Results}

FG 1: The striking feature in the KMOC was that 9 of the 11 moments recorded a genre shift with either intonation or chronotope changes supporting it; further analysis discovered 22 such shifts overall. Bakhtin's description (Sullivan 2012) of discourse direction facilitated this interrogation. While genres vary, some share a monological approach, where the author or speaker is him/herself further 'authorised' by the genre; it is an 'outside-in' discourse which carries historical force and intention, as in an epic or academic form, where the author/speaker shapes the hero/listener. Where the hearer wants to engage, $s /$ he may re-author the discourse, incorporating it into his/her voice with a changed intonation, such as an ironic tone, as 'inside-out' directionality, but the hero's remains subordinate to the authorial voice. A 'double-voiced' discourse, such as a blog or a microdialogue, contains more than one authorising position and several differently intoned responses to it. 


\section{Melodramatic genre, genres shifts and discourse direction}

The FG1 conversation began with discourse strongly resonating with Greek melodrama. Arrowsmith (1963) references Greek theatre as concerned with ideas rather than with moral character; a monological genre, it authorises ideas but gives limited scope to audience engagement. In its earliest form it included musical episodes (melo is Greek for musical) and later developed into the mediaeval mystery play, where the sung element was liturgical, reinforcing the dominant discourse (Bellinger 1927). Singer (2001), refer- ring to more modern melodrama, identifies pathos, moral polarisation, emotionalism and sensationalism as factors of the genre. Yet in Greek theatre a key role is played by the chorus, and Weiner (1980) makes a telling argument for them to be seen as singers and dancers enhancing the theatricality, but also prefiguring Brecht's 'alienation effect', of giving time and space to the audience to 'stop feeling and begin to think' (Weiner 1980, 211).

Illustratively, KM1 begins to create the scene:

Annie: Uum (2) Would I see:: (2) a man who'd been set upon (1) Would I actually see him (2) or her (1) Have I seen him or her (1) or have I (.) walked past not even noticing. (3)

R: $\quad$ So is your question answering one of (.) Brian's, is s your question (.) under what circumstances could you walk past, you're you're s suggesting ?

Annie: Sometimes I may not even notice (.) so so (1) being so self-absor::bed or focused (.) not necessarily self-absorbed but (.) focused on a (1) pa::th (.) don even notice $\uparrow$ the need. [Mmm] Maybe. (2) So it could be an answer couldn't it to Brian's question. (3)

R: $\quad$ So if we peel back those circumstances what would make us so (.) focussed $n$ so blind? (5) ((breath intakes/sighs))

We feel the melodrama as pathos in the lengthy pauses, the elongated words and the accentuation of Annie's delivery as an expectation of failure. When the researcher probes her meaning, Annie hardly breaks her rhythm; the regular emphases, repetitions, and elongations persist, almost hypnotically. The pauses lengthen, and though the facilitator prompts discussion, the dramatic atmosphere is increased by the prolonged silence, broken only by the sound of breathing and sighs. Time seems to stand still. Very slowly 'the chorus' responds:

Sam: Busyness? (4) Self-importance? (6)

Pris: Selfishness?(2)

R: $\quad$ Say again?

Pris: Selfishness?

R: Selfishness?

Jane: Prejudice? 
R: *Prejud(h)ice?* Carl: Everyday habit. Sam: Duty? (5)

Matt: Yeah, l'd say self-preoccupation (1) it's not (3) don't know whether that's selfish or whether it's busyness it's somewhere in between i it's just just tied up in (.) your own little world (7)

In singsong questioning, the chorus appears in the drama, not as actors but re-enforcing the dramatic scene-setting, following the main lead. The researcher's slight laugh triggers the beginning of awareness, Carl's prosaic, landed intonation signals a shift of consciousness and, after a collective baited breath of five long seconds, Matt's 'Yeah' shifts the discourse from the ill-defined hypnotic magical space to an owned world. The chronotope has 'thickened' to a lived reality ('everyday habit' rather than grand ideas), but the intonation remains hesitant, where he feels 'tied up' in a 'tiny' space relative to the sheer scope of the dramatic chronotope which he struggles to encapsulate: 'I it's just just ...' As the Choryphaeus of the Greek chorus, he lives the dichotomy between becoming an actor or remaining a theatrical adjunct. The collective voice continues in the melodic/hypnotic space.

Jane: Even doing what you think is the 个right thing?

Carl: $\mathrm{Mmm}$

Matt: or the $\uparrow$ wise thing.

Carl: $\mathrm{Mmm}$

Jane: the wise thing

Matt: I don't think it's particularly wise to go and (.) $\mathrm{hm}($.$) put yourself on the line in$ that scenario (4)

The full generic shift is from dramatic to the ironic 'wise' which demands interrogation, and Matt's voice authors the challenge that without reflection, pausing to think as well as feel, we are only players in a 'scenario'.

An overview of the generic shift pattern is précised in Table 1 where discourse 'soundbites' illustrate the following analysis. Though genres shift, the monological direction does not, remarkably through ten interactions, which holds the discourse at its melodramatic level of moral extremes. Melodrama meets 'expert' genre (Table 1, 3), but the authoring voice remains outside-in, the intonation hammers 'questions' home as statements, limiting possibility for any listener to re-shape either the discourse or her approach to it. The pattern of dominant Greek actor and tentative hero continues; though the latter takes the discourse into an inside-out potential reframing, he is met repeatedly with strong authorial response, even within Frank's discourse (Table 1, 9). A professional manager, Frank shifts to that genre to 'evaluate' the emotions one 'encounters' rather than feels; he approaches the question as an extradiegetic administrator of events, and his supporting chronotope shift re-structures ill-defined magical space as 'precisely' timed, 'situated' and 'brought' to date. But, now accessible in felt time and space, Frank seems actually to experience fear as an 'absolute'. Focused, precise evalua- 
tion gives place again to universalised angst, and with passionately intoned persuasion, he unexpectedly re-authors the hearers to realise 'you know' that 'they don't care', and reasserts the moral polarisation of melodrama.

Table 1: FG1 Genre shifts (précis)

\begin{tabular}{|c|c|c|c|c|}
\hline & Ref & Discourse type & Qualities & Soundbite \\
\hline 1 & $2: 1$ & $\begin{array}{l}\text { Annie: Tragedic } \\
\text { /Melodrama }\end{array}$ & $\begin{array}{l}\text { Hypnotic, distance, } \\
\text { Outside-in voice } \\
\text { Undefined space but } \\
\text { intoned expectation of } \\
\text { judgement }\end{array}$ & Uum (2) Would I see:: (2) \\
\hline 2 & $2: 2$ & $\begin{array}{l}\text { Matt: Chorus / } \\
\text { Ironic }\end{array}$ & $\begin{array}{l}\text { Chorus within } \\
\text { melodrama } \\
\text { Inside-out discourse } \\
\text { Struggling for } \\
\text { boundaries }\end{array}$ & $\begin{array}{l}\text { it's somewhere in between } \\
\text { it's just just tied up in (.) your } \\
\text { own little world (7) }\end{array}$ \\
\hline 3 & $3: 2$ & $\begin{array}{l}\text { Sam: } \\
\text { Expert/Melodra } \\
\text { ma }\end{array}$ & $\begin{array}{l}\text { Outside-in } \\
\text { Static } \\
\text { Intonation } \\
\text { monological, } \\
\text { No interrogative } \\
\text { sound }\end{array}$ & $\begin{array}{l}\text { So (1) can we really change } \\
\text { (3) when we encounter the } \\
\text { story of others. Does that } \\
\text { change us. }\end{array}$ \\
\hline 9 & $6: 3$ & $\begin{array}{l}\text { Frank: } \\
\text { Professional/Ra } \\
\text { tional }\end{array}$ & $\begin{array}{l}\text { Reasoning the } \\
\text { feelings; } \\
\text { Reverts to moral } \\
\text { polarisation. } \\
\text { Outside-in, passionate } \\
\text { persuasion } \\
\text { Moves towards } \\
\text { generic from } \\
\text { evaluative }\end{array}$ & $\begin{array}{l}\text { Somebody like me would } \\
\text { start to evaluate .. (2) .. you } \\
\text { know, with the Islamic State } \\
\text { (.) .. you know, these people } \\
\text { don't care ... will stop at } \\
\text { absolutely nothing (1) you } \\
\text { know. }\end{array}$ \\
\hline 11 & $8: 1$ & Harry: Narrative & $\begin{array}{l}\text { Inside-out } \\
\text { Text dialogues with } \\
\text { lived experience of }\end{array}$ & $\begin{array}{l}\text { I can't talk about my } \\
\text { Indi(h)an experience } \\
\text { without emotion and I felt (.) }\end{array}$ \\
\hline
\end{tabular}




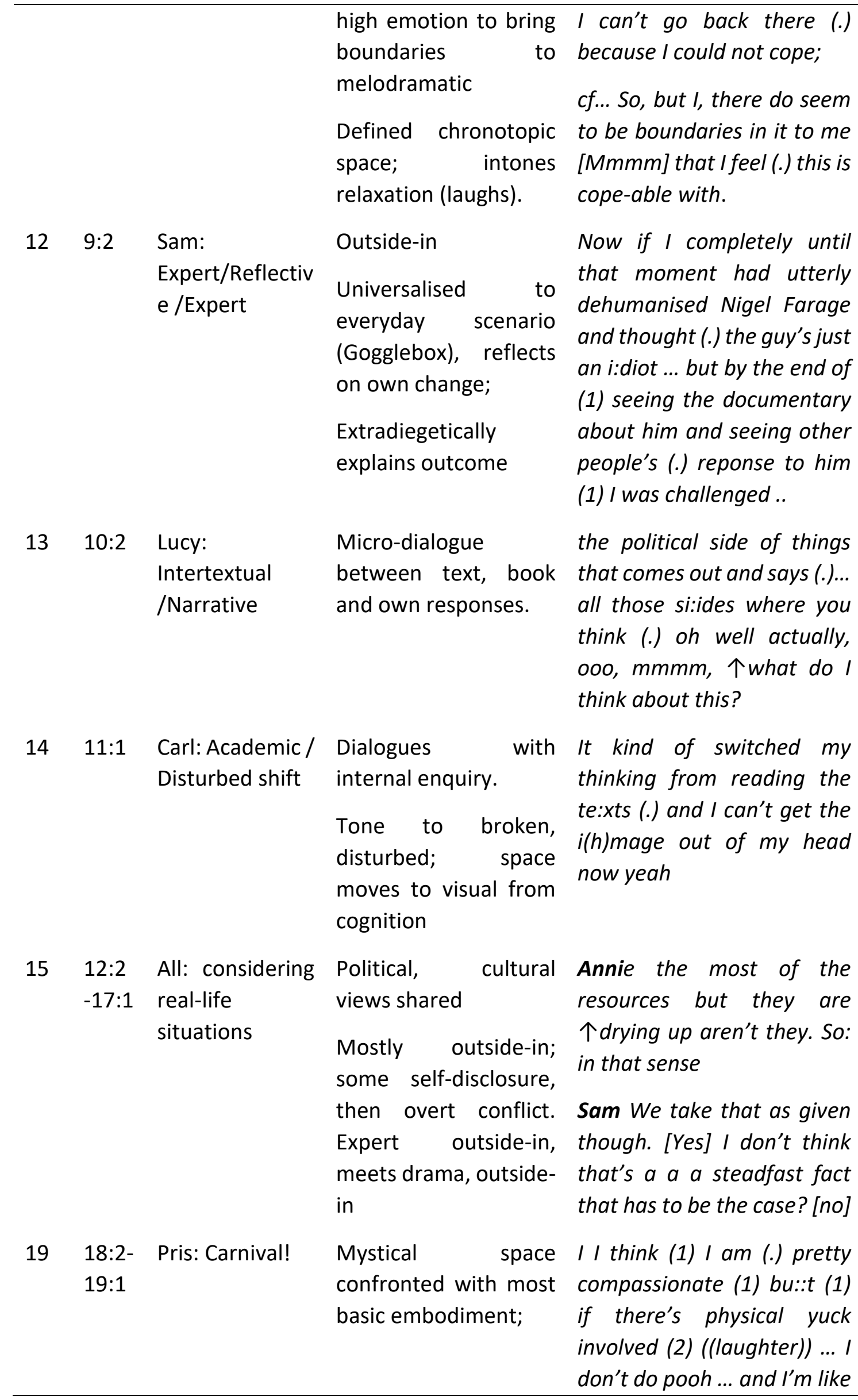




Feeling space (.) eeeer ((loud laughter))
increasingly tightens: then (.) I (1) don't feel very
mother, less for aunt, compassionate (1) but (.)
even less aunt-in-law... [you do it. You do it] I do it.
to none, but I do it! (Mm] (3)
Internally persuaded
discourse.

The significant change in the group's conversation begins with Harry's contribution (Table 1, 11) in a multi-voiced, narrative approach. It evokes Bakhtin's theory of 'novelness' (Holquist 2002), which puts 'different orders of experience - each of whose languages claims authority on the basis of its ability to exclude others, into dialogue with each other' (85). Different voices offer a diversity of truths in a narrative genre which challenges a hearer's single subjectivity. Harry's 'inter-narrative' discourse speaks simultaneously from his own felt paralysis in the face of human need; he also parodically re-authors the comments of others into the text, and warmly invokes a sense of relief at the human need for boundaries. The shared laughter, the comfortingly hummed agreement indicates a safe, 'actual' meeting space between the varied perspectives of a story which Harry feels, intones and lands as 'actually I find (.) the story quite boundaried (.) and practical (.)' The significance of the generic shift to a multi-voiced experience is underlined by the re-framing of the subsequent discourse. The answering 'expert' genre is this time interspersed with self-reflection; an intertextual microdialogue considers how changing information makes Lucy feel; and a strongly monological academic discourse also shifts midstream from considered 'objectivity' to breathy imagery. From there, conversation is equably shared awhile, before flowing into two monological utterances (Table 1, 15) but this time the group immediately re-structures the conversation into a carnival of shared, shouted, elemental human interaction. Pris's further discourse, and her feedback, described the internally-persuasive discourse of ' do it' (Table 1, 19), as a significant internal shift. Her moment of understanding, perceived in Harry's narratively framed boundaries of felt human experience, moved her from wanting to believe herself compassionate to the self-conscious conviction that her desire is actually matched in behaviour.

FG 2: It was unsurprising, given the history and make-up of this group that they majored in this same egalitarian genre, where, of $31 \mathrm{KMs}$ at least 22 were clearly narrative in style.

\section{Narrative genre, threshold moments and double-voiced discourses}

Bakhtin's (1981) work on the novel suggests it as a literary form which expresses the struggle between voices and subjectivity, and, as such, a descriptive experience of consciousness, illustrative of the different ways in which a person might function as a 
complex, multi-voiced self. Bakhtin describes these different aspects of selfhood as 'Ifor-myself' as 'spirit', and the 'soul' experience of the social self as 'I-for-other' and 'Other-for- me'. None of these exist alone but interact in a reflexive dialogue which continually re- shapes the self's consciousness. 'I-for-myself', whose background values and perspective are inaccessible from the subject position, becomes aware of the essential need of the 'other-for-me'. Equally needed by the other, 'I-for-other' generates contingency, or re- shaping potential, by disrupting the 'hero's' own subjectivity The self discovers the other either in embodied conversation between author and hero, or in 'internal' dialogue between other-authored voices, social embeddedness, and 'I-formyself', along with the responsibility to negotiate this reflective space. Movement and re-shaping of the parti- cipants are therefore the inherent dynamics of the narrative genre, which is full of such 'threshold' moments, and are significantly marked by 'double-voiced' discourse.

This was the distinctive discourse of FG2. James arrived with severe reservations about the text of 'the Good Samaritan,' which patterned the deeply affective discourse, in which different participants re-imagined historical/present/potential landscapes (chronotopes) to facilitate James's inclusion into the shared, 'in-between' space of the conversation. Several distinctive examples of such double-voiced interactions were further analysed. They present sometimes as different voices in the conversation, or in KMs signified by heightened intonation, 'microdialogue' where an individual expresses his own 'internal' discussion, or as intertextual chronotopes. Examples are listed in Table 2 and further exposed here.

Table 2: FG2 Double voiced discourse (précis).

\begin{tabular}{|c|c|c|c|c|}
\hline & Ref & Discourse type & Qualities & Soundbite \\
\hline 1 & $1: 3$ & $\begin{array}{l}\text { James: } \\
\text { Microdialogue }\end{array}$ & $\begin{array}{l}\text { Re-authoring } \\
\text { religious authority } \\
\text { and John's voice: } \\
\text { anticipating } \\
\text { judgement, word } \\
\text { with a loophole, } \\
\text { hesitation, appeal } \\
\text { to collaboration. }\end{array}$ & $\begin{array}{l}\text { SO THE SAMARITANS...I had a } \\
\text { quick chat with my Rabbi this } \\
\text { morning (.) ... and I had an } \\
\text { amazing conversation with } \\
\text { John ...and, be:ing me, <I } \\
\text { wondered whether I was } \\
\text { over-reacting which I (.) have } \\
\text { a tendency to do: > IT } \\
\text { DEPENDS HOW LONG YOU } \\
\text { WANNA } \downarrow \text { spend on this. }\end{array}$ \\
\hline 2 & $6: 2$ & $\begin{array}{l}\text { Javed: Inter- } \\
\text { textual } \\
\text { chronotope }\end{array}$ & $\begin{array}{l}\text { Re-framing the } \\
\text { space where James } \\
\text { can stand; } \\
\text { overlapping socio- } \\
\text { cultural space/ } \\
\text { self's felt space/ his } \\
\text { own simultaneous }\end{array}$ & $\begin{array}{l}\text { Javed OK Hheh } \mathrm{Ho}(h)(.) \text { but } \\
\text { like if anything thou:gh (1) } \\
\text { that your explanation and } \\
\text { you're in a bit o' the context of } \\
\text { (.) what was going on with } \\
\text { that time (.) sort of like (.) } \\
\text { politically or socially with the } \\
\text { the different Jewish sort of }\end{array}$ \\
\hline
\end{tabular}




$\begin{array}{ll}\text { identity space (next } & \text { tribes and stuff adds to that? } \\ \text { section)/ } & \text { rather than takes it away? ... } \\ \text { 'Lingering'; inside } & \text { You probably also (.) like felt } \\ \text { (.) a } \uparrow \text { part of? Errm (.) of that } \\ \text { (.) like of that (.) sort of (.) } \\ \text { 'Geist' or 个 whatever you } \\ \text { want to个 ca:Il it? Errm (.) And } \\ \text { I think that's a good thing. (2) } \\ \text { The fact that he:'s because } \\ \text { he's not doing it from outside } \\ \text { so can't really be (.) anti- } \\ \text { Semetic because he himself is } \\ \text { a Semite } \\ \text { James No no. He ca:n't [Mm] } \\ \text { but the wa:y it it's been used } \\ \text { for me [Yeah] certainly in my } \\ \text { own education a::nd in the } \\ \text { broader debate <has felt that } \\ \text { it } \\ \text { is> No YOU'RE RIGHT (.) } \\ \text { absolutely. [Yeah] But (.) I } \\ \text { suspect that (.) wh:en Jesus } \\ \text { was telling the story he } \\ \text { wouldn't ha- he couldn't have } \\ \text { been anti-Semitic because } \\ \text { he's h'es [he's a Jew] Yes } \\ \text { exactly }\end{array}$

3 11:3 Olu \& James: Socratic dialogue; Are you perceiving the Socratic slipping from narrative from this experience dialogic encounter in Europe over the last (1) of understanding in which has been difficult like I between to said [Ye:ah] or are you interrogating the actually engaging with the interlocutor: no text with it, [So can you connection. identify

James Feels like

Olu your mind is wounded. Can you actually, have you seen

James that that's why I was sort of 


\section{Olu Yeah yeah] (4)}

$4 \quad 22: 1 \quad$ Lou \& James

$5 \quad 33: 1$ Joe
Conversation: intradiegetic

Openheartedness about content; polar opposites in approach.

James Erm (2) Yeah I think I see your point.

James ... but I do try and make links with people, sorry, so I'M REALLY INTRIGUED BY WHEN YOU SIGNED that piece of paper, (.) what you 个 meant.

Lou I didn't even 个think about 个it, I just do:ve straight 个in.[Yeah] I'm not interested in the 个boundaries of it= James $=\uparrow \uparrow$ rea: $/ l y=$ Lou =or the $\uparrow$ thought of $\uparrow$ it, or the (.) it's just like (.) just like, ooh, just put me right in there, and I'll swim along and see what I figure out as I go 个along.

James ${ }^{\circ}$ Good on you ${ }^{\circ}$

Lou NO, good on you, nothing, no, because (.) you're having a moment of, you know, colliding worlds and every time I talk to you:, ((laughter)) I have one, and I really appre:ciate it .... an and there's 个something in that that's incre:dibly challenging and also very very ri::ch ...t when you sit with the other: , it it requires you to expa::nd and to hhhhh [ Hhh] have your head blown off and then you put your head back 个on again, thinking well I'm richer for that experience $=$

Intertextual: Text, the thing that I was thinking was that, you know this word Re-authors Lou's interrogation of lived reality; love, and that's why this little book by Badieu is so $\downarrow$ good ... 


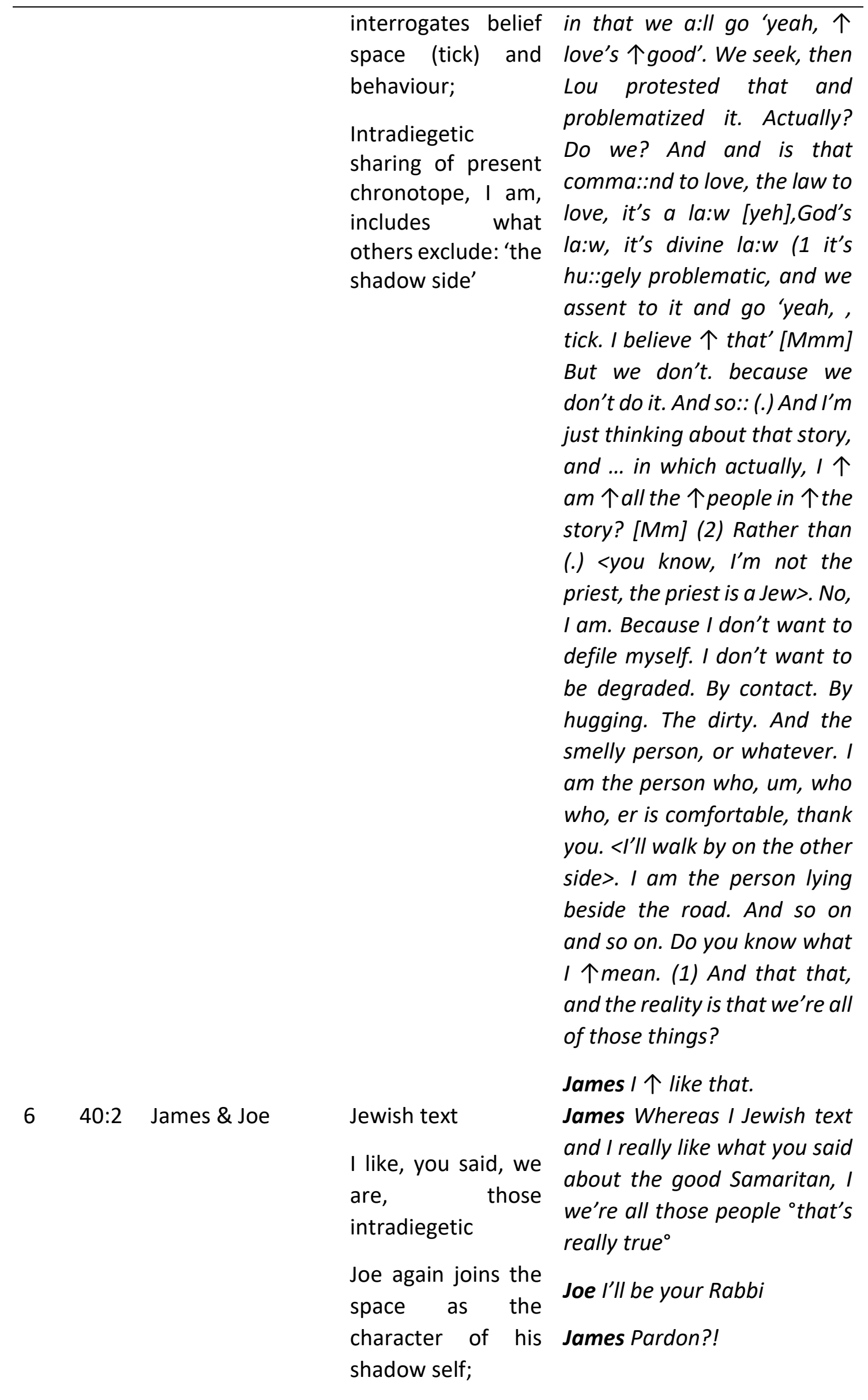


In James's microdialogue (Table 2, 1), he re-authors both his Rabbi and a friend's voices as valid authorities, though the religious is intoned as primary; 'my' Rabbi is very immediate, while the dropped volume and future reference distances John's contribution, despite its description as 'amazing'. The third voice is James's own, probing his right to question the text, perceived as anti-Semitic; he appeals to religious authority to establish his own voice through the 'word with a loophole', an appeal to an ideal addressee to vindicate him in the anticipation of judgement of 'be::ing me'. Yet his desire for the others in the room is most pressing, as his raised voice engages them and overpowers any other voices. He reduces the question about his beliefs to 'this piece of paper' (The Consent Form's affirmation of desiring 'to love rather than harm a potential enemy') demoting its significance with a laughing question, and appeals again, loudly, for affirmation about the relevance of his contribution. It is the intonation that fills his utterance with movement. It indicates the seeking author, questioning which voice is his own, among others to which he refers with ambivalent commitment, in movement towards awareness and potential agency.

In Javed's (Table 2, 2) intertextual chronotope, he re-authors James's religious conviction within a broader motif, a chronotope that holds open the boundaries to 'add' wisdom and expose the simultaneity of differently lived perspectives. His upwardly lilting intonation is felt as a gentle invitation to this landscape which includes Jesus, the contested hero, who stands in the shared experience of the learned rebel, like James stands in his own 'facticity'. The third space that encompasses the other two, the '(zeit) Geist', is the calling and identity space, to which James becomes sensible and radically shifts his approach ('NO, YOU'RE RIGHT absolutely'). Movement between the voices is clearly evident but the conversation moves on with James still ambivalent. Olu's voice (Table 2, 3) reasserts authorial discourse which shapes the hero: his attempt to probe James's psychology abnegated dialogue, and, clearly, at that moment, any understanding. Two findings are exposed. Firstly, engagement with the other may offer a 'transcendent moment', certainly as movement between voices, but can miss the shared understanding between discourse participants, Gadamer's 'matter at hand'. Secondly dialogism itself may risk becoming a 'super-genre', potentially constructing the dialogue with a hidden end in view. Though able to offer marvellously intertextual, alternative chronotopes to James, Javed's directionality displays a lack of mutuality, insisting twice, 'the other thing as well that I was gonna say'. His frequent default to a dominantly authorial discourse embodies a further discovery supported by the data from FG1, and FG3. Monological authorship may generate self-aware movement in another, but not 
agentic clarity. We discover in Javed's own, later self-reflection that an agentic, transcendent self emerges in an egalitarian dialogical interaction that involves movement in both author and hero, in fact emerging as a consciously relational self (39:2).

Javed: And for the first time in this conversa:tion, ss, this this is a bit of a self- reflection and stuff, right (.) I I'm quite intelligent? I know that about myself, right, and I know that I can usually enter into a conversation or any sort of situation and, like, kind of, handle it? But for the first time in this conversation, that level of exchange that we've just had, I felt (.) 个really vulnerable? [Mm Mm] D'you know what I $\downarrow$ me:an Uu:mm

'This conversation' has triggered a sensibility in Javed that has moved him away from 'intelligence' and autonomy, to a different 'level' of vulnerability, mutuality, and 'exchange'.

Javed: . . because you ask questions, you really probed me? where because I don't think I've really asked where that comes from, but it really is 个important to me? D'you know what I me:an of like people $\uparrow$ doing that? People, you know. I am willing (.) to put myself (.) into a $\uparrow$ vulnerable position (.) for people to give me (.) the chance to really get to know me? ... D’you know what I $\downarrow$ me:an

He embodies the discovery both of the 'risk' to the self's present understanding in an encounter with the other (Davey 2006) and the utter necessity of such vulnerability to 'give me (.) the chance to really get to know me'. His self-awareness is triggered by the 'probing' of the other's voice. A remarkable shift in his intonation is evidenced here, from interrogative, with the frequent ' $D$ 'you know what I 个me:an,?' seeking common ground with the audience. Sullivan (2012) cites Bakhtin as describing such an 'interruption' as an opportunity, even the invitation of a seeking author, for the other to “"penetrate" self-consciousness' (Sullivan 2012, 53). The changed intonation from rising to falling, 3 times, and only in the above data, is remarkable, suggesting that such 'penetration' has taken place. Earlier (32:3) Javed had contributed even more emotively about the nature of engaging lovingly with an Other.

Javed: Like, are you willing to be violated, ... . are you willing to have your identity violated by knowing the other, but actually it also poses a big question mark over the way that we understand $\uparrow$ love? ...

1Lou: But the ke::y (2), the ke::y element in transformation is vulnerability. [Yeh]. So when you say a violation, I can- I struggle with that word, cos it's like (.) violation is something you do to me, I don't want done to me (.) whereas, the ability to open yourself up to be hurt, vulnerable, is is (.) also my $\uparrow$ choice, as well

The lived experience here is intoned from a deeply personal place of self-transcendence that actually requires intimate, sensual, embodied, costly interaction with otherness, but in an agentic choice which recognises the essentiality of relationship. It suggests the full implication of Bakhtinian Self's 'spirit' in the 'soul' connections. Frankl (2011) has this Other-oriented-Self, 'the self (that) chooses the Thou,' as truly agentic, 
transcendently activated by the moral conscience 'in the emotional and intuitive, nonrational depths of the spiritual unconscious' (Frankl 2011, loc 523).

Joe demonstrates the movement towards this spirit/soul connection, in the discourse to which most feedback referred (Tables 2, 5 and 6). He stretches himself to embrace a broad self-consciousness to overlap with James's lived experience. He re-frames love as a shared human experience, appealing to philosophy, experience, others in the room, as well as including the ancient, disputed text. He draws the chronotope as itself transcen- dent in its scope, high to the heavens' 'divine la: $w$ ', generalised to the 'a::II', but as personal as a 'tiny' book, as 'actually' today's 'problematized' experience. It appears both shockingly penetrative ('Pardon?!') and kindly wooing to James's sensibility, ('I really really like that'); it is equally self-re-shaping for Joe as the researcher re-authors his voice, intradiegetically, in the narrative.

R: And I am the Samaritan, I am the enemy.

Joe: Yeah. Yeah, absolutely. A:nd, interestingly (1) when I: (.) reach out to the other, I'm 个beginning to get into my own shadow? (1) That bit of myself that I regard as the enemy. That's how I (.) begin to encou:nter (.) my own shadow self [I like that] (1) Maybe. (5)

Given the level of feedback, and the lived impact for James and Joe in the dialogue, this data set contributes particularly to the enquiry. It evidences both movement ('beginning to get into') and transcendent re-shaping ('encou:nter my own shadow self') in one, and in other, a shift 'back from' separated text, belief and cognition to 'really really liking' the experientially positive affect where 'we're all of those things', the shared embodied experiences. The shift takes place for both, when 'I-for-other' and 'Other-for-me' coincide in shared understanding, at the level of moral con-science. 'When I: (.) reach out' lingers over the ' $I$ ', pausing to connect self-conscious 'I-for-myself' outwardly; where, only in relation with the 'other', 'I begin to 'encou::ter my own shadow self'. Joe's feedback refers to this shadow as a felt defensiveness of his social history. He transcended it in his movement into the re-imagined, inclusive chronotope which allowed a re-shaping encounter. James's sensibility of this inclusion spontaneously integrated the resisted text into ' $I$ ', in 'whereas I Jewish text and I really like. . .' His feedback explained it happened when the other stood in the place of his painfully received understanding and re-framed it. Such self and other re-shaping suggests a necessary, indeed transcendently reframed 'meeting place', and self-persuaded, even sacrificial movement into it. FG 3: By contrast, in FG3 it was difficult to identify even 8 KMs in which two shifts were evident. It was unexpected that most participants struggled with the English language, making the intonation particularly difficult to interpret. Heightened emotion was observable, also complex to interpret, since it often reflected frustration with communication difficulties and the impact on selfconsciousness was highly uncertain, and the feedback forms gave no further clarity. This lack of nuanced participation perhaps necessitated the default genre. Buhler's (2010) exposé of Platonic dialogue refers to its early use in facilitating discussion between 
different theological and denominational perspectives, and it was into this genre, and its related Socratic questioning, that the discourse fell.

\section{Socratic/platonic drama}

The main evidence from this group reinforced the finding that strongly monological discourse, albeit influenced by the lack of linguistic flexibility, militated against significant re-shaping. As listed (see Table 3), dramatic sub-genres were evident as the mood moved from courtroom drama, with an expectation of judgement, to more romantic drama, potentially more hopeful but with the same teleological expectation of solution rather than encounter. Several other interactions also, often somewhat confrontationally, sought resolution, some of which involved the researcher. Even though aware of the dynamics, in the pressure of the dominant discourse she was cast, and sometimes responded, in the role of 'Socrates', the reference point of resolution. An age difference between the analyst and the younger group could, culturally, have added to this effect, as might the role of 'academic researcher'. It is mentioned here, not *as a 'word with a loophole', seeking vindication from the reader*, but as reflective feedback on the frustrating constraint of monological genres. It suggests that the epistemological for- matting of 'truth'-seeking conversation can lock even alert participants out of the shared space that facilitates agentic change. It also suggests further interrogation is needed into the impact of very significant difference in age, language and/or culture (indeed 'other- ness') on a participant's chosen 'seeking' or 'needy' approach. The step between aware- ness and agency is again exposed.

Table 3: FG3 Examples Data sets of Platonic/Dramatic subgenres (précis).

\begin{tabular}{|c|c|c|c|c|c|c|}
\hline Ref & Participant & \multicolumn{2}{|l|}{ Context } & $\begin{array}{l}\text { Genre } \\
\text { Discourse }\end{array}$ & $\begin{array}{l}\text { Emotional } \\
\text { Register }\end{array}$ & Elaboration \\
\hline $\begin{array}{l}1 \\
6: 2\end{array}$ & Josh & $\begin{array}{l}\text { "Who } \\
\text { the } \\
\text { enemy?" }\end{array}$ & is & $\begin{array}{l}\text { Socratic } \\
\text { dialogue, } \\
\text { interrogating } \\
\text { 'Socrates' }\end{array}$ & $\begin{array}{l}\text { Combative, } \\
\text { crowing, } \\
\text { yielding, } \\
\text { extremes of } \\
\text { volume; } \\
\text { becoming } \\
\text { ambivalent, } \\
\text { struggling and } \\
\text { back to } \\
\text { assertive. }\end{array}$ & $\begin{array}{l}\text { Idealised, } \\
\text { 'eternally' static } \\
\text { belief space } \\
\text { where lived } \\
\text { experience } \\
\text { brings } \\
\text { disruption. } \\
\text { Resolved in } \\
\text { separating } \\
\text { experience to } \\
\text { 'small', 'long } \\
\text { time ago' }\end{array}$ \\
\hline $\begin{array}{l}2 \\
14: 1\end{array}$ & Andrea & $\begin{array}{l}\text { Can } \\
\text { change? }\end{array}$ & I & $\begin{array}{l}\text { Microdialogue } \\
\text { COURTROOM } \\
\text { DRAMA } \\
\text { interrogating }\end{array}$ & $\begin{array}{l}\text { Disrupted, } \\
\text { guilty, }\end{array}$ & $\begin{array}{l}\text { Legalised space, } \\
\text { beginning in } \\
\text { generalised } \\
\text { reasonable }\end{array}$ \\
\hline
\end{tabular}




\begin{tabular}{|c|c|c|c|c|c|}
\hline & & & $\begin{array}{l}\text { her own } \\
\text { motives }\end{array}$ & $\begin{array}{l}\text { accusation, } \\
\text { confession }\end{array}$ & $\begin{array}{l}\text { equilibrium } \\
\text { looking for } \\
\text { vindication but } \\
\text { ending in } \\
\text { conflict } \\
\text { (degenerative) }\end{array}$ \\
\hline $\begin{array}{l}3 \\
15: 3\end{array}$ & Alessia & $\begin{array}{l}\text { Can a } \\
\text { person } \\
\text { change? }\end{array}$ & $\begin{array}{l}\text { Microdialogue } \\
\text { ROMANTIC } \\
\text { DRAMA }\end{array}$ & $\begin{array}{l}\text { Heightened } \\
\text { happiness and } \\
\text { disappointment } \\
\text { (actual tears) }\end{array}$ & $\begin{array}{l}\text { Romantic, } \\
\text { relaxed meeting } \\
\text { place, } \\
\text { Conflicts looking } \\
\text { for equilibrium } \\
\text { (regenerative) }\end{array}$ \\
\hline $\begin{array}{l}5 \\
27: 2\end{array}$ & Maria & $\begin{array}{l}\text { Can I just } \\
\text { say a final } \\
\text { word? }\end{array}$ & $\begin{array}{l}\text { SUMMARY } \\
\text { JUDGEMENT }\end{array}$ & & \\
\hline
\end{tabular}

\section{Discussion}

Hesitations, grounded in the on-going debate around accurate and 'conceptually appropriate' methods of enquiry, particularly in 'inter-cultural' research (Frijda and Jahoda 1966) may yet be expressed about some of the findings suggested here. Two charges which might be levelled at this research will be the choice of such an innovative (unscientific?) methodology as 'aesthetic' discourse analysis, and a potential 'over-interpretation' of the data. The inter-cultural argument, extending to inter-disciplinary research, is addressed by the Loughborough School critiquing 'the way notions of individuality are built into methods (which psychology uses)... at a very deep level' (Hepburn and Wiggins 2005) with a re-worked vision of personhood that is crucial to an enquiry into self-conscious agency. It might now be safely argued, especially in today's multi-cultural but globalised world, that participative methods of tracking inter-actions between very different people with shared values would be of great relevance, as long as grounded in authentic research methods. This enquiry was able to listen to the deeper structure of discourse as the felt sensibility of participants in the challenge, potential, and responsibility of engaging with difference. Using aesthetic analysis to track shifting values and sensibilities, grounded both in a philosophical hermeneutical methodology and in Bakhtin's robust research on changing genre, chronotope and intonation, gave good evidence that these can function as 'the sound that value makes' (Sullivan and McCarthy 2004). The issue of interpretation is one that must be faced in all qualitative approaches, and reflective honesty about axiology, a desire for innovative hopefulness in the present world scene has been offered. A potentially disruptive style of reporting is also acknowledged, diverting from 'academic' expression, to what some have termed a poetic bent, which may invite further criticism of researcher obtrusiveness. It is deliberately disruptive both as an example and in hope, since, while instituted (e.g. 
academic) genres inform readers, a more narrative, 'felt' interaction may allow for changes of approach, even self-transcendence, in participants. Participating in the lived research experience was impactful and informative, which is hopefully reflected in employing relevant genres to report it. So also, the corroboration of feedback from all involved gives information and confidence that the selection of KMs did indeed highlight such impactful shifts and moments of different understanding.

Three distinct findings from the research can be summarised. Firstly, the disjunction discovered by Darley and Batson (1973) between self-confessed values and behaviour was also identified between spoken idealised values and the intoned expectation of disappointment in living out those values for many in this research. The disjunction remained unchallenged where the conditions for reflecting on the ambivalence were not established. Where individual moments of reflectivity offered potential movement towards self-awareness, the centripetal pull of a monological genre was found to be severe, and agentic behaviour curtailed. It suggested the potential correlation between authorial outside-in discourses and an unreflective, residually positivistic epistemology, which seeks to expose 'truth' in verbal communication.

Secondly, the disjunction was successfully challenged. A distinct shift to engage in a narrative approach significantly moved the conversation from the default mode of 'thinking rather than feeling', and stimulated very different interaction. A moment of transcendent re-shaping happened in co-operative, carnival discourse when Pris reauthored an internally persuasive worldview of hopeful potential in boundaried demand. She lived a moment of understanding herself as morally and agentically related to those around her, which transcended her earlier self-consciousness. Both the discourse analysis and her and others' reflective reporting suggest an ontological reshaping beyond the self-protectionism of an individualised consciousness which otherwise, seemingly always, internally contradicts a cognitive choice of altruistic values.

James also evidenced self-transcendent experience in immediate intonation, re-framed chronotope and thoughtful self-reports, triggered by the agentic movement of Joe, the seeking author. Re-framing himself with James in an open, rather than contested chronotope, his movement was from an historic perception to being together 'in' a lived event, as elementally different from a verbal, 'truth'-seeking interaction as water is from air.

Thirdly then, awareness is potentially transcendent, but agency is the self-persuaded act to 'dive in' to a reconfigured consciousness, where 'vocation' (chosen values) 'coincides with the movement of the calling toward itself' (Agamben 2005). The transcendent effect occurred where shared space was created into which the participants could move from or beyond their authorial isolation and felt like a centripetal spinning together. The possibility exists therefore that these 'self-transcendent experiences' are merely evidence of a trans- figured social construction rather than personally agentic. The sterility of an atomised self is increasingly disputed (e.g. Becker and Marecek 2008), and the integration of other-oriented worldviews (e.g. Uchida and Kitayama 2009) is changing the collective understanding. The discourse analysis however, in the fine- 
grained enquiry of language, directionality, space, time and movement, intonation and affect argues more for a moral, internally-persuasive participation in a re-configured, loving and appreciative sociality.

\section{Conclusion}

Deliberate difference necessarily demanded self-conscious movement from participants in these conversations. They either moved in avoidance of the 'Samaritan' other, the enemy of one's comfortable homeostasis, or towards the 'Good Samaritan' neighbour whose help out of isolated paralysis was needed. The evidence suggests that the latter re-orientation co-occurs with epistemological and ontological re-shaping, and the effect of the choice to engage with a rebalanced consciousness of self in relationship with, rather than to, others. In some cases, it was sufficiently energetic to re-frame the discourse and other participants' self-awareness, as well as the shared understanding of socially constructed concepts such as 'enemy'. Further enquiry into how to facilitate opportunities to engage in re-shaping discourse with such moral and ethical potential is surely indicated.

\section{Notes}

1. A scientifically acceptable control group would not be possible, given that 'otherness' can never be eliminated. The level of homogeneity in this group was distinctly higher in terms of shared worldview and cultural experience, to offer potential comparisons.

\section{Disclosure statement}

No potential conflict of interest was reported by the authors.

\section{Funding}

Dr. Eiroa-Orosa has received funding from the European Union's Framework Programme for Research and Innovation Horizon 2020 (2014-2020) under the Marie SkłodowskaCurie Grant Agreement No 654808

\section{References}

Agamben, G. 1998. Homo Sacer: Sovereign Power and Bare Life. Translated by D. Stanford, CA: Stanford University Press.

Agamben, G. 2005. The Time that Remains. Translated by Dai. Stanford, CA: Stanford University Press.

Alison, J. 2007. "Love Your Enemy: Within a Divided Self" In St. Martin-in-the-Field Autumn Education Program. London. Available at http://www.jamesalison.co.uk/pdf/eng50.pdf 
Arrowsmith, W. 1963. "A Greek Theater of Ideas." Arion: A Journal of Humanities and the Classics 2 (3): 32-56. Available at http://www.jstor.org/stable/20162850

Bakhtin, M. M. 1981. The Dialogic Imgaination: Four Essays. Translated and edited by Emer. M. Holoquist. Austin, TX: University of Texas Press.

Batson, C. D., N. Ahmad, and D. A. Lishner. 2009. "Empathy and Altruism." In The Oxford Handbook of Positive Psychology, edited by C. R. Snyder and S. J. Lopez. Oxford, UK: Oxford University Press. Baumeister, R. F. 1987. "How the Self Became a Problem: A Psychological Review of Historical Research." Journal of Personality and Social Psychology 52 (1):163-176. doi:10.1037/0022-

3514.52.1.163.

Baumeister, R. F. 2011. "Self and Identity: A Brief Overview of What They Are, What They Do, and How They Work." Annals of the New York Academy of Sciences 1234. 48-55. doi:10.1111/j.1749- 6632.2011.06224.x.

Becker, D., and J. Marecek. 2008. "Dreaming the American Dream: Individualism and Positive Psychology." Social and Personality Psychology Compass 2 (5):1767-1780. doi:10.1111/j.1751- 9004.2008.00139.x.

Bellinger, M. F. 1927. "A Thousand Years of Quiescence and the Beginning of Sacred Drama": A Short History of the Drama. New York City: Henry Holt.

Buhler, K. E. 2010. Sola Scriptura: A Dialogue. Kindle. CreateSpace Independent Publishing Platform. Cloninger, C. R. 1999. "A New Conceptual Paradigm from Genetics and Psychobiology for the Science of Mental Health." Australian and New Zealand Journal of Psychiatry 33: 174-186.

doi:10.1046/j.1440-1614.1999.00533.x.

Darley, J. M., and C. D. Batson. 1973. "“From Jerusalem to Jericho": A Study of Situational and Dispositional Variables in Helping Behavior." Journal of Personality and Social Psychology 27 (1): 100-108. doi:10.1037/h0034449.

Davey, N. 2006. Unquiet Understanding: Gadamer's Philosophical Hermeneutics. Albany, NY: State University of New York Press.

Dugatkin, L. A. 2006. The Altruism Equation: Seven Scientists Search for the Origins of Goodness.

Princeton, NJ: Princeton University Press.

Frankl, V. E. 1966. "Self-Transcendence as a Human Phenomenon." Journal of Humanistic Psychology 6: 97-106. doi:10.1177/002216786600600201.

Frankl, V. E. 2011. Man's Search for Ultimate Meaning. New York: Insight Books.

Frijda, N., and M. Jahoda. 1966. "On the Scope and Methods of Cross-Cultural Research1."

$\begin{array}{llllll}\text { International Journal of } & \text { Psychology } 109-127 .\end{array}$ doi:10.1080/00207596608247118. 
Gadamer, H. G. 1981. Reason in the Age of Science. F. G. Lawr. Cambridge, MA: MIT Press. Gadamer, H. G. 2004. Truth and Method. 2nd ed. New York City: Crossroad.

Gergen, K. J. 1991. The Saturated Self. New York City: Basic Books.

Haase, J. E., T. Britt, D. D. Coward, N. K. Leidy, and P. E. Penn. 1992. "Simultaneous Concept Analysis of Spiritual Perspective, Hope, Acceptance and SelfTranscendence." Journal of Nursing Scholarship 24 (2): 141-147. doi:10.1111/jnu.1992.24.issue-2.

Halkier, B. 2010. "Focus Groups as Social Enactments: Integrating Interaction and Content in the Analysis of Focus Group Data." Qualitative Research 10 (1): 71-89. doi:10.1177/ 1468794109348683.

Hepburn, A., and S. Wiggins. 2005. "Developments in Discursive Psychology." Discourse and Society 16 (5): 595-601. doi:10.1177/0957926505054937.

Holoquist, M. 2002. Dialogism: Bakhtin and His World. 2nd ed. London and New York City: Routledge.

Holoquist, M. 2010. "The Fugue of Chronotope." In Bakhtin' S Theory of the Literary Chronotope Reflections, Applications, edited by P. Borghart, 19-35. Gent, Belgium: Ginko Academia Press.

Keunen, B. 2000. "Bakhtin, Genre Formation, and the Cognitive Turn: Chronotopes as Memory Schemata." Comparative Literature and Culture 2: 2. doi:10.7771/14814374.1069.

Keunen, B. 2010. "The Chrontopic Imagination in Literature and Film: Bakhtin, Bergson and Deleuze on Forms of Time." In Bakhtin' S Theory of the Literary Chronotope Reflections, Applications, edited by P. Borghart, 35-57. Gent, Belgium: Ginkgo Academia Press.

Koltko-Rivera, M. E. 2006. "Rediscovering the Later Version of Maslow's Hierarchy of Needs: Self- Transcendence and Opportunities for Theory, Research, and Unification." Review of General Psychology 10 (4): 302-317. doi:10.1037/10892680.10.4.302.

Kwee, M. G. 2011. "Relational Buddhism: A Psychological Quest for Meaning and Sustainable Happiness." In The Human Quest for Meaning, edited by P. T. P. Wong, 249-273. New York City \& Hove, U.K.: Routledge.

Lomas, T., K. Hefferon, and I. Ivtzan. 2014. Applied Positive Psychology; Integrated Positive Practice.

London and Thousand Oaks, CA: Sage Publications.

Love, M., 2013. Leeds, a Workshop for Peace. Peace Review, 1-8. doi:10.1080/ 10402659.2013.759775. 
Madill, A., A. Jordan, and C. Shirley. 2000. "Objectivity and Reliability in Qualitative Analysis: Realist, Contextualist and Radical Constructionist Epistemologies." British Journal of Psychology 91 (1): 1- 20. doi:10.1348/000712600161646.

Maingueneau, D. 2002. "Analysis of an Academic Genre." Discourse Studies 4 (3): 319-342. doi:10.1177/14614456020040030401.

Maslow, A. H. 1971. The Farther Reaches of Human Nature. New York City: Viking.

Mitchell, R. H. 2011. Church, Gospel and Empire: How the Politics of Sovereignty Impregnated the West. Eugene, OR: Wipf \& Stock.

Oman, D. 2011. "Compassionate Love: Accomplishments and Challenges in an Emerging Scientific/Spiritual Research Field." Mental Health, Religion \& Culture 14 (9): 945-981. doi:10.1080/ 13674676.2010.541430.

Piedmont, R. L. 1999. "Does Spirituality Represent the Sixth Factor of Personality? Spiritual Transcendence and the Five-Factor Model." Journal of Personality 67 (6): 985-1013. doi:10.1111/1467-6494.00080.

Reed, P. G. 2009. "Demystifying Self-Transcendence for Mental Health Nursing Practice and Research." Archives of Psychiatric Nursing 23 (5): 397-400. Accessed July 1, 2014 http://www. ncbi.nlm.nih.gov/pubmed/19766931.

Schnell, T. 2011. "Individual Differences in Meaning-Making: Considering the Variety of Sources of Meaning, Their Density and Diversity." Personality and Individual Differences 51 (5): 667-673. doi:10.1016/j.paid.2011.06.006.

Schwartz, S. H. 1994. "Are There Universal Aspects in the Structure and Contents of Human Values?." Journal of Social Issues 50 (4):19-45. doi:10.1111/j.15404560.1994.tb01196.x.

Singer, B. 2001. Melodrama and Modernity: Early Sensational Cinema and Its Contexts. New York City: Columbia Univesity Press.

Stern, D. 2010. Forms of Vitality: Exploring Dynamic Experience in Psychology, The Arts, Psychotherapy and Development. Oxford, UK: Oxford University Press.

Stokoe, E., A. Hepburn, and C. Antaki. 2012. "Beware the 'Loughborough School' of Social Psychology? Interaction and the Politics of Intervention." British Journal of Social Psychology 51 (3): 486-496. doi:10.1111/j.2044-8309.2011.02088.x.

Sullivan, P. 2012. Qualititative Data Analysis Using a Dialogical Approach. London and Thousand Oaks, CA: Sage Publications.

Sullivan, P., and J. McCarthy. 2004. "Toward a Dialogical Perspective on Agency." Journal for the Theory of Social Behaviour 34 (3): 291-309. doi:10.1111/jtsb.2004.34.issue-3.

Ten Have, P. 2015. "Appendix A: Transcription Conventions." In Doing Conversation Analysis, edited by P. Ten Have, 216-217. London: Sage Publications.

Tileagă, C. 2006. "Representing the "Other": A Discursive Analysis of Prejudice and Moral Exclusion in Talk about Romanies." Journal of Community \& Applied Social Psychology 16 (1): 19-41. doi:10.1002/(ISSN)1099-1298. 
Uchida, Y., and S. Kitayama. 2009. "Happiness and Unhappiness in East and West: Themes and Variations." Emotion (Washington, D.C.) 9 (4): 441-456. Accessed May 27, 2014 doi:10.1037/1089-

2680.10.4.302.

Ward, G. 2005. Cultural Transformation and Religious Practice. Cambridge, UK: Cambridge University Press.

Weiner, A. 1980. "The Function of the Tragic Greek Chorus." Theatre Journal 32 (2): 205-212. doi:10.2307/3207113.

Westerman, M. A. 2013. "Making Sense of Relational Processes and Other Psychological Phenomena: The Participatory Perspective as a post-Cartesian Alternative to Gergen's Relational Approach." Review of General Psychology 17 (4): 358-373. doi:10.1037/a0034447.

Wong, P. T. P. 2012. "Introduction: A Quiet Positive Revolution." In The Positive Psychology of Meaning and Spirituality, edited by P. T. P. Wong, L. C. J. Wong, M. J. McDonald and D. W. Klaasen, 1-8. Birmingham, AL: Purpose Research. 